\title{
PEMAKAIAN BUAH BIT DAN UBI JALAR UNGU SEBAGAI PEWARNA ALAMI PADA PEMERIKSAAN PLAK SISWA/I SMP NEGERI 4 KEC. DATUK BANDAR TIMUR KOTA TANJUNG BALAI
}

\author{
Rawati Siregar \\ Jurusan Keperawatan Gigi Poltekkes Kemenkes Medan
}

\begin{abstract}
Abstrak
Apabila gigi tidak dibersihkan maka pada permukaan gigi akan terdapat lapisan transparan yang melekat erat yang dikenal sebagai lapisan plak gigi. Untuk mengetahui keberadaan plak dibutuhkan bahan pewarna yang dapat mewarnai permukaan plak. Kandungan zat pewarna betasianin pada buah bit dan antosianin pada ubi jalar ungu, berpotensi sebagai sumber bahan pewarna alami untuk melihat plak pada gigi. Penelitian ini bersifat deskriptif dengan menggunakan metode survei yang bertujuan untuk mengetahui peranan buah bit dan ubi jalar ungu untuk pemeriksaan plak pada Siswa/i SMP Negeri 4 Kec.Datuk Bandar Timur Kota Tanjung Balaidengan sampel 60 orang. Hasil penelitian menunjukkan bahwa nilai rata-rata indeks plak sesudah pengolesan buah bit sebesar 1,43 dengan kriiteria sedang dan ubi jalar ungu sebesar 1,13 dengan kriteria sedang. Penggunaan buah bit dan ubi jalar ungu dapat digunakan sebagai bahan alternatif pewarna alami untuk pemeriksaan plak. Rata-rata indeks plak setelah pengolesan buah bit sebesar 1,43 dan rata-rata indeks plak setelah pengolesan ubi jalar ungu sebesar 1,13.
\end{abstract}

Kata kunci : Buah Bit, Ubi Jalar Ungu, Indeks Plak

\section{Latar Belakang}

Kesehatan merupakan salah satu unsur dalam pembangunan nasional yang berguna untuk peningkatan dan pembangunan sumber daya manusia. Masyarakat yang sehat akan mewujudkan derajat kesehatan yang optimal. Menurut Word Health Organization (WHO) sehat adalah suatu keadaan sejahtera, sempurna fisik, mental dan sosial serta tidak hanya terbatas pada bebas dari penyakit atau kelemahan saja.

Menurut Undang Undang Kesehatan No. 36 tahun 2009 Pasal 93 ayat 1 dan 2 yaitu pelayanan kesehatan gigi dan mulut dilakukan untuk memelihara serta meningkatkan derajat kesehatan masyarakat yang dapat dilakukan dengan tindakan pencegahan, pengobatan penyakit gigi serta pemulihan kesehatan gigi yang dilaksanakan oleh pemerintahan setempat dan dapat juga dilakukan melalui pelayanan kesehatan gigi perseorangan, sekolah dan masyarakat.

Berdasarkan hasil Riset Kesehatan Dasar (RISKESDAS) tahun 2018, proporsi gigi rusak/berlubang di provinsi Sumatera Utara adalah sebesar 43,1\%. Prevalensi nasional Indeks DMF-T adalah 4,6\%. Indeks DMF-T lebih tinggi pada perempuan dibandingkan dengan laki-laki.

Masalah kesehatan gigi utama yang paling banyak dijumpai adalah penyakit karies gigi dan periodontal yang disebabkan oleh keadaan kesehatan gigi dan mulut yang buruk. Plak merupakan penyebab utama terjadinya karies (lubang gigi) dan penyakit periodontal (Boedihardjo, 1985).
Plak yang tipis memiliki warna yang sama dengan gigi sehingga tidak terlihat kecuali bila telah diwarnai dengan cairan pewarna. Cairan pewarna tersebut adalah disclosing agent, yaitu bahan yang mengandung pewarna kimia atau agen pewarna lainnya berupa larutan atau gelyang dapat mewarnai deposit bakteri pada permukaan gigi, lidah, dan gingiva.

Kita dapat mengetahui keberadaan plak dengan bantuan bahan pewarna plak. Bahan dasar pewarna plak yang umum digunakan adalah eritrosin, fuhsin, iodin, merkurokrom, mebromin, bismark brown, malachite green,fast green,two tone solutions dan pewarna histologis lainnya. Larutan $\mathrm{Na}+$-Fourescein juga dapat digunakan untuk mendeteksi plak. Zat warna akan diserap oleh glikoprotein sehingga plak dapat terlihat. Pengunaan bahan pewarna plak di bidang kedokteran gigi sebagai bahan pendeteksi plak dirasa belum efektif karena sosialisasi yang kurang dari para tenaga kesehatan gigi dan tempat penjualan yang terbatas.

Beberapa bahan dapat membuat alergi dan rasanya kurang menyenangkan bagi beberapa orang seperti iodin, ada pula fuhsin dan merkurokrom yang warnanya sulit dihilangkan, dan eritrosin yang bersifat karsinogenik, sehingga perlu dicari bahan alternatif lain yang lebih dikenal oleh masyarakat dan efektif. Bahan pewarna plak yang tersedia di pasaran beragam, berdasarkan warna ada yang berwarna merah, hijau, biru ataupun kuning, sedangkan berdasarkan sediaan ada yang berbentuk larutan, tablet, lozenges, dan wafer. 
Indonesia merupakan negara yang kaya akan sumber daya alam dan banyak tanaman yang telah dimanfaatkan oleh masyarakat dalam kehidupan seharihari, salah satunya adalah tumbuhan berwarna yang memiliki berbagai pigmen sebagai pewarna alami makanan. Pigmen alami tersebut yaitu klorofil, betakaroten, antosianin, betalain, dan lainnya. Berbagai penelitian telah membuktikan bahwa zat pewarna makanan, khususnya yang berasal dari tumbuhan, efektif digunakan sebagai bahan pewarna plak.

Ubi jalar ungu atau ketela rambat (Ipomoea batatas L.) adalah sejenis tanaman budidaya. Pigmen ungu pada pada ubi ungu bermanfaat sebagai antioksidan karena dapat menyerap polusi udara, racun, oksidan dalam tubuh dan menghambat penggumpalan sel-sel darah. Ubi jalar ungu mengandung senyawa antosianin yang berfungsi sebagai antioksida, antikanker, antibakteria, serta perlindungan terhadap kerusakan hati, jantung dan stroke.

Menurut Ekoningtyas (2016), bahan ubi jalar ungu dapat digunakan sebagai identifikasi keberadaan plak di permukaan gigi.

Warna ungu pada pada ubi jalar disebabkan oleh adanya pigmen antosianin yang tersebar dari bagian kulit sampai ke daging umbinya. Kandungan antosianin yang tinggi pada ubi jalar ungu mempunyai stabilitas yang tinggi dibanding antosianin dari sumber lain. Itulah sebabnya tanaman ini menjadi piihan yang lebih sehat dan sesuai dengan allternatif pewarna alami.

Salah satu sumber pewarna makanan yang belum banyak dimanfaatkan adalah buah bit. Warna merah pada buah bit yang berasal dari pigmen betasianin memberikan warna pekat dan diharapkan diserap glikoprotein sehingga dapat mewarnai plak. Menurut Hidayah (2016), bahan buah bit dapat digunakan sebagai bahan peawarna plak pada gigi.

Berdasarkan uraian diatas, peneliti ingin melakukan penelitian sederhana guna mengetahui peranan buah bit dan ubi jalar ungu untuk pemeriksaan plak pada Siswa/i SMP Negeri 4 Kec.Datuk Bandar Timur Kota Tanjung Balai.

\section{Rumusan Masalah}

Berdasarkan latar belakang, maka dapat dirumuskan masalah sebagai berikut: "Bagaimana Peranan Buah Bit dan Ubi Jalar Ungu untuk Pemeriksaan Plak pada Siswa/i SMP Negeri 4 Kec.Datuk Bandar Timur Kota Tanjung Balai? ”.

\section{Tujuan Penelitian}

1. Untuk mengetahui rata-rata indeks plak sesudah pengolesan buah bit pada Siswa/i SMP Negeri 4 Kec.Datuk Bandar Timur Kota Tanjung Balai.

2. Untuk mengetahui rata-rata indeks plak sesudah pengolesan ubi jalar ungu pada Siswa/i SMP Negeri 4 Kec.Datuk Bandar Timur Kota Tanjung Balai.

\section{Manfaat Penelitian}

1. Dapat memberikan masukan dan manfaat bagi perkembangan ilmu pengetahuan dalam bidang kesehatan khususnya di bidang kesehatan gigi dan mulut.

2. dapat memberikan informasi dan pengetahuan pada Siswa/i SMP Negeri 4 Kec.Datuk Bandar Timur Kota Tanjung Balai khususnya tentang buah bit dan ubi jalar ungu sebagai bahan yang dapat digunakan untuk melihat nilai kebersihan gigi dan mulut.

3. Menambah pengetahuan dan wawasan secara langsung dalam melakukan penelitian.

\section{Jenis dan Desain Penelitian}

Jenis penelitian yang digunakan adalah penelitian deskriptif dengan metode survey yang bertujuan untuk mengetahui peranan penggunaan buah bit dan ubi jalar ungu untuk pemeriksaan plak.

\section{Lokasi dan Waktu Penelitian}

Penelitian ini dilakukan di SMP Negeri 4 Kec. Datuk Bandar Timur Kota Tanjung Balai.

Penelitian dilakukan mulai dari bulan Februari sampai dengan bulan Desember 2018.

\section{Populasi dan Sampel Penelitian}

Populasi adalah keseluruhan objek penelitian atau objek yang diteliti (Arikunto, 2016). Populasi dalam penelitian ini adalah seluruh siswa/siswi SMP Negeri 4 yang berjumlah 60 orang.

Sampel adalah sebagian objek yang diteliti dan dianggap mewakili seluruh populasi (Notoatmodjo, 2017). Sampel dalam penelitian ini adalah seluruh populasi 60 orang sehingga disebut dengan populasi sampling. Dalam penelitian ini, populasi dibagi menjadi 2 kelompok yaitu kelompok pertama sebanyak 30 orang dengan pengolesan buah bit dan kelompok kedua sebanyak 30 orang dengan pengolesan ubi jalar ungu.

Teknik pengambilan sampel dalam penelitian ini adalah total sampling. Total sampling adalah teknik pengambilan sampel dimana jumlah sampel sama dengan populasi. Alasan mengambil total sampling karena jumlah populasi kurang dari 100, maka seluruh populasi dijadikan sampel penelitian.

\section{Jenis dan Cara Pengumpulan Data}

Data yang relevan diperlukan dan dikumpulkan untuk memperoleh jawaban diatas masalah dan persoalan penelitian yang telah dirumuskan. Sumber data yang digunakan dalam penelitian ini dibagi dalam 2 jenis, yaitu: Data Primer

Menggunakan data yang diperoleh langsung dari SMP Negeri 4 Kec.Datuk Bandar Timur Kota Tanjung Balai, dengan mengadakan pemeriksaan plak indeks secara langsung.

Data Sekunder

Gambaran umum biodata murid SMP Negeri 4 Kec.Datuk Bandar Timur Kota Tanjung Balai, yang diperoleh dari guru dan bagian administrasi. 


\section{Instrumen Pengumpulan Data}

Bahan :

1. Buah sebanyak 80 gram dipisahkan dari kulitnya, kemudian dihaluskan dan diambil sarinya sebanyak $30 \mathrm{ml}$.

2. Ubi jalar ungu sebanyak 80 gram dipisahkan dari kulitnya, kemudian dihaluskan dan diambil sarinya sebanyak $30 \mathrm{ml}$.

3 Kapas/cotton pellet.

Alat yang digunakan untuk pemeriksaan plak yaitu:

1. Kaca mulut

2. Sonde

3. Pinset

\section{Prosedur Penelitian}

Langkah-langkah penelitian yang dilakukan dalam pengumpulan data adalah sebagai berikut:

1. Mengumpulkan responden sebanyak 60 orang.

2. Memperkenalkan diri dan memberikan instruksi

3. Membagi responden menjadi 2 kelompok, dimana kelompok pertama dengan jumlah 30 orang untuk pengolesan buah bit dan kelompok kedua dengan jumlah 30 orang untuk pengolesan ubi jalar ungu.

4. Mempersiapkan alat dan bahan untuk penelitian.

5. Melakukan pemeriksaan plak sesudah pengolesan buah bit untuk kelompok pertama dan pengolesan ubi jalar ungu untuk kelompok kedua.

6. Mencatat hasil pemeriksaan pada lembar pemeriksaan.

7. Menginstrusikan responden untuk berkumurkumur.

\section{Pengolahan Data dan Analisa Data}

Data yang telah dikumpulkan diolah dengan manual dengan langkah-langkah segai berikut:

1. Editing

Memeriksa kelengkapan formulir pemeriksaan dengan tujuan agar data yang dimaksud dapat diolah secara benar.

2. Coding

Dalam langkah ini peneliti mengubah formulir pemeriksaan menjadi bentuk angka-angka yang berhubungan dengan variabel peneliti untuk memudahkan dalam pengolahan data.

3. Tabulating

Memasukkan hasil perhitungan dalam bentuk tabel, untuk melihat rata-rata dan persentase dari pemeriksaan yang diperoleh.

Data yang telah dikumpulkan dianalisa dengan langkah-langkah sebagai berikut:

1. Menghitung, rata-rata indeks plak pada Siswa/i

SMP Negeri 4 Kec.Datuk Bandar Timur Kota

Tanjung Balai setelah pengolesan buah bit.

2. Menghitung, rata-rata indeks plak pada Siswa/i

SMP Negeri 4 Kec.Datuk Bandar Timur Kota

Tanjung Balai sesudah pengolesan ubi jalar ungu. berikut:

Dianalisa menggunakan rumus rentang nilai sebagai

Setiap gigi diperiksa empat permukaan yaitu mesial, distal, lingual dan fasial dan kemudian skornya dihitung. Bila skornya berkisar 0-1 dikategorikan baik, 1,1-2 sedang dan 2,1-3 buruk.

\begin{tabular}{|c|l|}
\multicolumn{2}{c}{ Cara pemberian skor untuk indeks plak } \\
\hline KODE & \multicolumn{1}{c|}{ KRITERIA } \\
\hline 0 & Tidak ada plak pada gingiva \\
\hline 1 & $\begin{array}{l}\text { Dijumpai lapisan tipis plak yang melekat } \\
\text { pada margin gingiva di daerah yang } \\
\text { berbatasan dengan gigi tetangga }\end{array}$ \\
\hline 2 & $\begin{array}{l}\text { Dijumpai tumpukan sedang deposit } \\
\text { lunak pada saku gingiva dan pada } \\
\text { margin gingiva dan atau pada } \\
\text { permukaan gigi tetangga yang dapat } \\
\text { dilihat langsung }\end{array}$ \\
\hline 3 & $\begin{array}{l}\text { Terdapat deposit lunak yang banyak } \\
\text { pada saku gusi dan atau pada margin dan } \\
\text { permukaan gigi tetangga. }\end{array}$ \\
\hline
\end{tabular}

Untuk satu gigi $=$

iı ımlah celı ın ıhcknr dari emnat nermı ıkaan

Untuk keseluruhan gigi =

$$
\frac{\text { iı ımlah cknr nlak }}{\text { jumlah gigi yang ada }}
$$

\section{Hasil Penelitian}

Data yang dikumpulkan adalah hasil penelitian yang dilakukan terhadap siswa-siswi SMP Negeri 4 Kec.Datuk Bandar Timur Kota Tanjung Balai. Pengumpulan data dilakukan dengan pemeriksaan langsung kemulut siswa-siswi yang menjadi sampel. Dari penelitian yang dilakukan, maka diperoleh data siswa dengan skor indeks plak menggunakan larutan sari buah naga dan larutan sari buah bit. Setelah seluruh data terkumpul, maka dibuat tabel distribusi frekuensi sebagai berikut:

\section{Distribusi Frekuensi Rata-rata Indeks Plak Sesudah Pengolesan Buah Bit Pada Siswa-siswi SMPN 4 Kec.Datuk Bandar Timur Kota Tanjung balai}

\begin{tabular}{cccc}
\hline Kriteria & $\begin{array}{c}\text { Jumlah } \\
\text { (n) }\end{array}$ & $\begin{array}{c}\text { Jumlah } \\
\text { Indeks } \\
\text { Plak }\end{array}$ & $\begin{array}{c}\text { Rata-rata } \\
\text { Indeks } \\
\text { Plak }\end{array}$ \\
\hline Baik & 8 & 7 & 0,87 \\
Sedang & 10 & 14,5 & 1,45 \\
Buruk & 12 & 21,34 & 1,77 \\
\hline Total & 30 & 42,84 & 4,09 \\
\hline
\end{tabular}

Berdasarkan tabel 4.1 diatas menunjukkan rata-rata indeks plak dengan buah bit, terdapat 8 responden dengan kriteria baik $(0,87), 10$ responden dengan kriteria sedang $(1,45), 12$ responden dengan kriteria buruk $(1,77)$. Rata-rata indeks plak pada siswa/i adalah 1,43 


\section{Distribusi Frekuensi Rata-rata Indeks Plak Sesudah Pengolesan Ubi Jalar Ungu Pada Siswa-siswi SMPN 4 Kec.Datuk Bandar Timur Kota Tanjung Balai}

\begin{tabular}{cccc}
\hline Kriteria & $\begin{array}{c}\text { Jumlah } \\
\text { (n) }\end{array}$ & $\begin{array}{c}\text { Jumlah } \\
\text { Indeks } \\
\text { Plak }\end{array}$ & $\begin{array}{c}\text { Rata-rata } \\
\text { Indeks } \\
\text { Plak }\end{array}$ \\
\hline Baik & 13 & 21,2 & 1,63 \\
Sedang & 8 & 3,41 & 0,42 \\
Buruk & 9 & 9,16 & 1,01 \\
\hline Total & 30 & 33,77 & 3,06 \\
\hline
\end{tabular}

Berdasarkan tabel 4.2 diatas menunjukkan rata-rata indeks plak dengan ubi jalar ungu, terdapat 13 responden dengan kriteria baik $(1,63), 8$ responden dengan kriteria sedang $(0,42), 9$ responden dengan kriteria buruk (1,01). Rata-rata indeks plak siswa/i adalah 1,13

\section{A. Pembahasan}

Plak dipermukaan gigi dapat dipakai sebagai salah satu indikator kebersihan mulut, plak memiliki sifat melekat pada permukaan gigi. Plak tidak dapat terlihat kecuali apabila telah diwarnai dengan bahan pewarna. Dijelaskan pula bahwa plak adalah suatu biofilm sendiri diartikan sebagai komunitas bakteri yang terorganisasi dengan baik, melekat kuat pada struktur organik maupun anorganik dan sulit dilepaskan dengan hanya berkumur.

Karies gigi dan penyakit periodontal adalah contoh penyakit terbanyak yang pada dasarnya disebabkan oleh aktivitas mikroorganisme patogen di dalam rongga mulut (Hebbal, dkk., 2012). Penyebab utama terjadinya karies dan penyakit periodontal adalah plak gigi. Plak adalah suatu lapisan transparan yang melekat erat pada permukaan gigi. Plak terdiri dari protein dan bakteri, $70 \%$ dari bakteri itu berasal dari air liur. Plak terbentuk segera setelah selesai menyikat gigi (Mumpuni, 2013).

Menurut Fatmasari, dkk, (2017), diketahui bahwa ubi jalar ungu dan buah bit dapat dijadikan bahan untuk melihat plak pada gigi dengan nilai rata-rata indeks plak sesudah pengolesan ubi jalar ungu sebesar 1,358 dan buah bit sebesar 1,942. Rata-rata indeks plak buah bit lebih besar dibandingkan rata-rata indeks plak pada ubi jalar ungu.

Tabel 4.1 dan 4.2 menunjukkan bahwa bahan pewarna dengan bahan dasar pewarna alami dari buah bit dan ubi jalar ungu dapat menunjukkan keberadaan plak. Hasil penelitian yang telah dilakukan tentang penggunaan buah bit dan ubi jalar ungu untuk pemeriksaan plak pada Siswa-siswi SMP Negeri 4 Kec.Datuk Bandar Timur Kota Tanjung Balai . Berdasarkan tabel 4.1 dapat diketahui bahwa indeks plak dengan pengolesan buah bit memiliki kategori baik sebanyak 8 responden dengan skor 0,87 , yang memiliki kategori sedang sebanyak 10 responden dengan skor 1,45, yang memiliki kategori buruk sebanyak 12 responden dengan skor 1,77 dan rata-rata indeks plaknya adalah sebesar 1,43. Berdasarkan tabel
4.2 dapat diketahui bahwa indeks plak dengan pengolesan ubi jalar ungu memiliki kategori baik sebanyak 13 responden dengan skor 1,63, yang memiliki kategori sedang sebanyak 8 responden dengan skor 0,42 , yang memiliki kategori buruk sebanyak 9 responden dengan skor 1.01 dan rata-rata indeks plaknya adalah sebesar 1,13

Setelah dilakukan penelitian dengan buah bit dan ubi jalar ungu, terlihat bahwa kedua bahan pewarna tersebut dapat digunakan untuk pemeriksaan keberadaan plak pada permukaan gigi.

Dengan hasil penelitian ini dapat diketahui bahwa buah bit dan ubi jalar ungu dapat digunakan sebagai bahan alternatif alami untuk pemeriksaan indeks plak.

\section{Simpulan}

Berdasarkan hasil penelitian serta pembahasan dapat disimpulkan sebagai berikut:

1. Rata-rata indeks plak sesudah pengolesan buah bit adalah sebesar 1,43.

2. Rata-rata indeks plak sesudah pengolesan ubi jalar ungu adalah sebesar 1,13.

3. Buah bit dan ubi jalar ungu dapat digunakan sebagai bahan alternatif alami untuk pemeriksaan plak.

\section{Saran}

Berdasarkan hasil penelitian diatas, maka peneliti memberikan saran sebagai berikut:

1. Diharapkan kepada Siswa/i SMP Negeri 4 Kec.Datuk Bandar Timur Kota Tanjung Balai dapat menggunakan buah bit dan ubi jalar ungu untuk melihat kebersihan gigi dan mulut..

2. Diharapkan penelitian ini dapat menjadi bahan refrensi di perpustakaan Politeknik Kesehatan Medan Jurusan Keperawatan Gigi

3. Diharapkan dapat menambah wawasan bagi penulis tentang penggunaan buah bit dan ubi jalar ungu untuk pemeriksaan plak. Semoga penulis dapat mengaplikasikan pada diri sendiri dan masyarakat dalam menjaga kebersihan gigi dan mulut.

\section{Daftar Pustaka}

Besford, J., 1996,Mengenal Gigi Anda: Petunjuk Bagi Orang Tua,Jakarta: Arcan.

Boedihardjo, 1985, Pemeliharaan Kesehatan Gigi Keluarga, Surabaya: Airlangga University Press

Ekoningtyas, E,A dkk., 2015, Potensi Kandungan Kimiawi Dari Ubi Jalar Ungu (Ipomoea Batatas L) Sebagai Bahan Identifikasi Keberadaan Plak, Jurnal Kesehatan Gigi, Vol.03, 1-6, Juni 2016

Fatmasari, D dkk, 2007, Larutan Buah Bit dan Ubi Jalar Ungu Sebagai Bahan Identifikasi Keberadaan Plak Gigi, Jurnal Kesehatan Gigi, Vol.04, 1, Juni 2007

Gardjito, M., A. Djuwardi, E Harmayani, 2013, Pangan Nusantara : Karakteristik dan Prospek untuk Percepatan Diversifikasi Pangan, Jakarta: Kencana Prenada Media Group 
Hakim A., 2018, Perbandingan Daya Tembus Pewarna Antara Disclosing Solution (Larutan Pengungkap) Buatan Pabrik dengan Ekstrak Daging Buah Naga Merah (Hylocereus costaricencis),

http://repository.unej.ac.id/handle/123456789/89 322, diakses tanggal 24 Februari 2019.

Hebbal, dkk, 2012, Effectiveness of Herbal and Flouride Toothpaste on Plaque and Gingival Scores Among Residents of a Working Women's Hotel, Oral Health PrevDent, 10 (4) :101

Hidayah N, dkk, 2016, Ekstrak Umbi Bit (Beta Vulgaris L.) Sebagai Bahan Pewarna Plak, Vol.03, 185190, Desember 2016

Hongini, S.Y dan M Aditiawarman, 2012, Kesehtan Gigi Dan Mulut, Bandung: Pustaka Reka Cipta.

Mumpuni Y, dkk, 2013, 45 Masalah dan Solusi Penyakit Gigi dan Mulut, Yogyakarta : Andi Publisher

Nisa F., 2015, Perbedaan Efektifitas Ubi Jalar (Ipomea Batatas L.) Ungu dan Bahan Disclosing Solution (Bahan Kimia) Sebagai Bahan Identifikasi Plak, https://fakhrunnisasite.wordpress.com, diakses tanggal 10 Februari 2019.
Notoatmodjo, S., 2017, Metodologi Penelitian Kesehatan, Jakarta: PT Rineka Cipta.

Pintauli, S dan T Hamada, 2016, Menuju Gigi Dan Mulut Sehat: Pencegahan Dan Pemeliharaan, Medan: USU Press

Riset Kesehatan Dasar (RISKESDAS), 2018, Badan Penelitian dan Pengembangan Kesehatan Kementrian RI Tahun 2018. Jakarta: Balitbangkes.

World Health Organization, Indonesia National Health System Profile,Indonesia: WHO, 2010, [disitasiOktober 2013] diaksesdari: http://www/search.who.int/LinkFiles/Indonesia_C HP-Indonesia.pdf 